\title{
Bioactive substances of the Techirghiol therapeutic mud
}

\author{
Mihail Hoteteu $^{1,3,}$ Constantin Munteanu ${ }^{1,3}$, Elena Valentina Ionescu ${ }^{2}$, Roxana Elena Almășan² \\ ${ }^{1}$ Romanian Balneology Association \\ ${ }^{2}$ Techirghiol Balnear and Rehabilitation Sanatorium \\ ${ }^{3}$ SC Biosafety S.R.L.
}

\section{(cc) BY-NC-ND}

Coresponding author: Mihail Hoteteu

E-mail address: office@bioclima.ro

Peer-reviewed by: Gabriela Dogaru, "Iuliu Haţieganu" University of Medicine and Pharmacy Cluj-Napoca

Liviu Lazăr, University of Oradea, Faculty of Medicine and Pharmacy

\begin{abstract}
The study aims to characterize Techirghiol's sapropelic mud both by determining the organic and inorganic composition of the constituent phases and by isolating some compounds of humic substances.

The distribution between the solid and liquid phases of the peloid of the Ca2+, Mg2+, Fe3+cations, PO43- anion, bioactive compounds of the protein, lipid and carbohydrate classes as well as the phosphatase activity of Techirghiol sapropelic mud are analyzed.

The mud is fractionated using the $\mathrm{pH}$ and solvent polarity variation and is spectrophotometrically characterized based on absorption in the wavelength range 340-700 nm humic acids and fulvic acids differentiated on the basis of solubility and molecular mass.
\end{abstract}

Key words: Peloidotherapy, mud, humic substances, fulvic acids

\section{Introduction}

Maturated mud or muddy suspensions with curative and / or cosmetic properties are complex mixtures of fine granulated materials, mineral or marine water and organic compounds with biological activity (Tserenkhand, 2016, Munteanu and Hoteteu, 2011).Thus, peloids are natural or artificial mud obtained by mixing water (thermal, sea or lake / river) with organic or inorganic substances from geological or biological processes (Munteanu et all, 2014).

Ever since ancient times people used mud when they had available for healing or beauty. The use of the mud, especially the spring, has its origins since antiquity. In ancient Egypt, the ill people are anointed with mud brought Nile during overflow. Regarding the therapeutic effects of the peloids, papyruses written 4400 years ago found that Egyptians used peloids to treat burns, contractions, paralysis, gynecological diseases, and, as Galen mentions, they used mud taken from the Nile bed. King Herod and Queen Cleopatra used mud from Dead Sea water for medical and cosmetic purposes (Ma'or et al., 2006).

The first written instructions for the use of mud in the treatment of diseases indicating the duration of treatment and the way of application correlated with lists of pathologies were formulated by clerics and doctors from the 17th century, but their application dates back to the 12th-14th centuries (Gomes et al., 2013 Veniale et al., 2007)

Peloids have a therapeutic effect due to biologically active substances, organo-mineral, iron, copper, aluminum, amino acids, carbohydrates and antibiotics, vitamins, hormones (Carretero et al., 2006; Munteanu, 2017).

In terms of their physical and chemical composition, peloids are complex heterogeneous systems consisting of two solid phases and a liquid phase. The solid phase consists of the crystalline skeleton and the colloidal component, and the liquid phase is the peloid solution that is the carrier of the therapeutic effect (Potpara, 2012).

\section{LIQUID PHASE}

Water, anions , cations

Water is the most important component, directly proportional to the amount of colloids.

Mineral substances - the amount of which depends on the rock and water structure of the basin. Mineral mud (50-70\%), then sapropelic (20-40\%) and peat (below 20\%) have the greatest amount of mineral substances.

Oligoelements (ug/kg) with a pronounced pharmacological effect (Fe, Co, J, $\mathrm{Br}$ and $\mathrm{B}$ ), involved in the enzymatic processes $(\mathrm{J}, \mathrm{Fe}, \mathrm{Cu}, \mathrm{Mo}$, $\mathrm{Zn}, \mathrm{Co}, \mathrm{Mn}, \mathrm{Ni}, \mathrm{Ba}, \mathrm{Sr}, \mathrm{Cd}$ ), elements (As, Pb, Hg, $\mathrm{V}$ and $\mathrm{F}$ ), not yet elucidated biological role (Ti, Zr, Ir, Cs).

Gases (CO2, H2S, SO2) 
Biologically active substances - protein hydrolysates, carbohydrates, aminoacids, enzymes .

SOLID PHASE

1. Crystal framework (peloid skeleton) determines mechanical structure

Oxides (SiO2, Al2O3, Fe2O3, $\mathrm{CaO}, \mathrm{MgO}, \mathrm{Na} 2 \mathrm{O}$, $\mathrm{K} 2 \mathrm{O}$, TiO2, MnO,),

2. Colloid complex - plastic hydrophilic basis which absorbs moisture and defines thermal properties

Inorganic component: $\mathrm{Fe}(\mathrm{HS}) 3, \quad \mathrm{Fe}(\mathrm{OH}) 3$, $\mathrm{Al}(\mathrm{OH}) 3, \mathrm{H} 2 \mathrm{SiO} 3$

Organic component - humic substances: humin, humic and fulvic acids.

The purpose of this study is to determine the chemical and biochemical characteristics of Techirghiol's sapropelic mud, the distribution between the solid and liquid phases of the peloid of inorganic and organic compounds from the classes of proteins, lipids and carbohydrates and to fractionate and characterize the biologically active humic substances present in the peloid.

\section{Methodology}

The determinations were made using total crude mud, liquid phase and solid phase. The solid and liquid phases of the crude mud were isolated by centrifuging the mud for 15 minutes. at $6000 \mathrm{rpm}$. The values were calculated as $1 \mathrm{~g}$ of crude mud considering the ratio between the solid and the liquid phase 1: 2.12 determined by dehydration of the mud at $90^{\circ} \mathrm{C}$ for $24 \mathrm{~h}$ (Lamarr, 2014).

Determination of the protein content of the Techirghiol mud

The proteins in the sample react with the copper (II) ions in the alkaline medium forming a colored complex which can be measured spectrophotometrically at $545 \mathrm{~nm}$ (Gornall et al., 1949).

Determination of the lipid content of the Techirghiol mud

The triglycerides in the sample under the successive action of lipase, glycerol kinase, glycerol 3 phosphate oxidase and peroxidase form a colored complex which is measured spectrophotometrically at $500 \mathrm{~nm}$ (Bucolo și David, 1973).

Determination of hydrolysed carbohydrate content of Techirghiol mud

The glucose present in the sample forms, under the action of glucoxidase and peroxidase, a spectrophotometrically measurable complex at 500 nm (Trinder, 1969).

Determination of phosphatase activity from Techirghiol mud

Alkaline phosphatase catalyses the transfer of the phosphate group from 4-nitrophenylphosphate to 2amino-2-methyl-1-propanol in the alkaline medium, releasing 4-nitrophenol. Catalytic concentration is determined based on the rate of formation of 4nitrophenol, measured at $405 \mathrm{~nm}$ (IFCC, 2011).

Determination of calcium content from Techirghiol mud

The sample calcium reacts with arsenazo III, forming a color complex that can be dosed spectrophotometrically at $650 \mathrm{~nm}$ (Michaylova and Illkova, 1971).

Determination of iron content in Techirghiol mud

The ferric ions present in the sample are reduced to the ferrous form under the action of hydroxylamine. Ferrous ions react with ferrozine and form a colored complex, which can be measured spectrophotometrically at $560 \mathrm{~nm}$ (Stookey, 1970).

Determination of magnesium content in Techirghiol mud

Magnesium present in the sample reacts with blue xylidyl in alkaline medium producing a color complex that can be determined spectrophotometrically at $520 \mathrm{~nm}$. The presence of EGTA in the reagent avoids interference with calcium (Chromýa et al., 1973)

Determination of phosphorus content in Techirghiol mud

The inorganic phosphorus in the sample reacts in acidic medium with molybdate to form phosphomolybdate, which can be dosed spectrophotometrically at $340 \mathrm{~nm}$ (Gamst and Try, 1980).

The fractionation of humic substances was carried out by extraction of the mud in alkaline solution (1:5 $\mathrm{KOH} 0.5 \mathrm{~N}$ ) with the separation of humine and organic residues. The alkaline solution was brought to $\mathrm{pH}$ 1-2 with conc. $\mathrm{HCl}$. precipitating humic acids (Saito and Seckler, 2014).

The fulvic acids left in the acid solution were determined spectrophotometrically (Gan et al, 2007). Fulvic acids were subclassified by molecular weight using ethyl alcohol (Enkh-Oyun et al., 2013) and those soluble in the hydroalcoholic extract were determined spectrophotometrically. 


\section{Results:}

The chemical compounds determined in the Techirghiol mud are shown in Table 1. An increased distribution of inorganic compounds in the solid phase of the peloid is observed which indicates their absorption involving the inorganic phase bound to the insoluble humic material is largely constituted of clay minerals and $\mathrm{Al}$ and Fe hydroxides (Baglieri et al., 2014).

The ratio of the concentrations of inorganic substances between the solid phase and the liquid phase shows a variation in the order $\mathrm{P}>\mathrm{Mg}>\mathrm{Fe}>$ Ca. Helal's elemental characterization of humic fractions (2011) shows that fulvic acids contain $22 \%$ more hydrogen atoms than carbon atoms, 21\% more oxygen than carbon, and 14\% more carboxyl groups than humic acids. This implies that fulvic acids are more reactive than cations or, in other words, fulvic acids contain several functional groups of acidic nature, especially $\mathrm{COOH}$, total fulvic acid (900-1400 meq $/ 100 \mathrm{~g}$ ) is considerably higher than that of humic acids (400-870 meq/100g) (Yamauchi et al., 1984).

Organic substances reveal increased absorption of carbohydrates and proteins, which are mainly found in the solid phase as a result of biochemical transformations of natural organic matter, plant residues and animal waste during the humification process (Kosobucki and Buszewski, 2014).

Correlated with the high phosphorus content of the solid phase of the Techirghiol mud, the phosphatase activity of the solid phase is more than 6 times that in the liquid phase. The increased concentrations in the solid phase are explained mainly by the fact that according to the molecular aggregation model, the organic component of the peloids contains microbial biomass, organic layers on mineral particles and organic precipitates (Milanovskii and Shein, 2002). Also, the presence of unconventional electron donoracceptor bonds (EDA) has been demonstrated between the aromatic systems of the organic compounds and the sorption sites on the surface of minerals, organic matter and oxidized particles, in particular cation-n, $n-\pi$ EDA, $\pi-\pi$-EDA and hydrogen- $\pi$ donor-acceptor interactions that are more energetically strong than nonspecific hydrophobic interactions, including the van der Waals forces (Keiluweit and Kleber, 2009).
Table 1. Chemical and biochemical characteristics of Techirghiol

\begin{tabular}{|l|r|r|r|r|}
\hline & $\begin{array}{l}\text { Crude } \\
\text { mud }\end{array}$ & $\begin{array}{l}\text { Solid } \\
\text { Phase }\end{array}$ & $\begin{array}{l}\text { Liquid } \\
\text { Phase }\end{array}$ & $\begin{array}{l}\text { Solid } \\
\text { Phase / } \\
\text { Liquid } \\
\text { Phase }\end{array}$ \\
\hline \multicolumn{4}{|c|}{ Organic substances } \\
\hline $\begin{array}{l}\text { Protein substances (mg/g } \\
\text { mud) }\end{array}$ & 46.83 & 38.60 & 8.83 & 4.4 \\
\hline Lipids (mg/g mud) & 23.67 & 14.11 & 4.71 & 3.0 \\
\hline $\begin{array}{l}\text { Carbohydrates (mg/g } \\
\text { mud) }\end{array}$ & 5.63 & 4.64 & 0.912 & 5.1 \\
\hline \multicolumn{5}{|c|}{ Inorganic substances } \\
\hline Ca (mg/g mud) & 0.30 & 0.30 & 0.17 & 1.8 \\
\hline Mg (mg/g mud) & 0.70 & 0.67 & 0.14 & 4.8 \\
\hline Fe ( $\mu$ g/g mud) & 2.96 & 2.01 & 0.63 & 3.2 \\
\hline P (mg/g mud) & 25.55 & 24.04 & 4.46 & 5.4 \\
\hline $\begin{array}{l}\text { Phosphatase activity } \\
\text { (U/L/g mud) }\end{array}$ & 17.68 & 8.99 & 1.43 & 6.3 \\
\hline
\end{tabular}

It is commonly believed that peloids are predominantly formed from humic substances occurring during the humification process of the organic material. The heterogeneity of the molecular weight of numerous individual compounds with different chemical compositions containing biogenic elements $(\mathrm{C}, \mathrm{H}, \mathrm{N}, \mathrm{O}, \mathrm{P}, \mathrm{S})$ in carboxyl, phenol, alcohol, peptide, amide and other functional groups causes the humic acids to be polydispersed, heterogeneous, polyfunctional. The humification process includes the processes associated with chemical bond decomposition and mineralization (Fourti et al., 2010) and occurs essentially in two stages: the decomposition of the organic substrate into simplest elements followed by the synthesis and re-synthesis of these simple substances which cause the appearance humic substances (Savel'eva et al., 2010).

The fractionation of humic substances from Techirghiol sapropelic mud (Fig.1) was based on the properties of humic acids to be completely soluble at $\mathrm{pH} 13$ and completely insoluble at $\mathrm{pH}$ 1, being completely soluble in less than one hour at $\mathrm{pH}>10$. $\mathrm{pH}$ between 10 and 9 dissolution is slower but almost complete, and at $\mathrm{pH} 8.5$ and 8, more than $60 \%$ and $40 \%$, respectively, of humic acids are soluble (Brigante et al., 2007). 


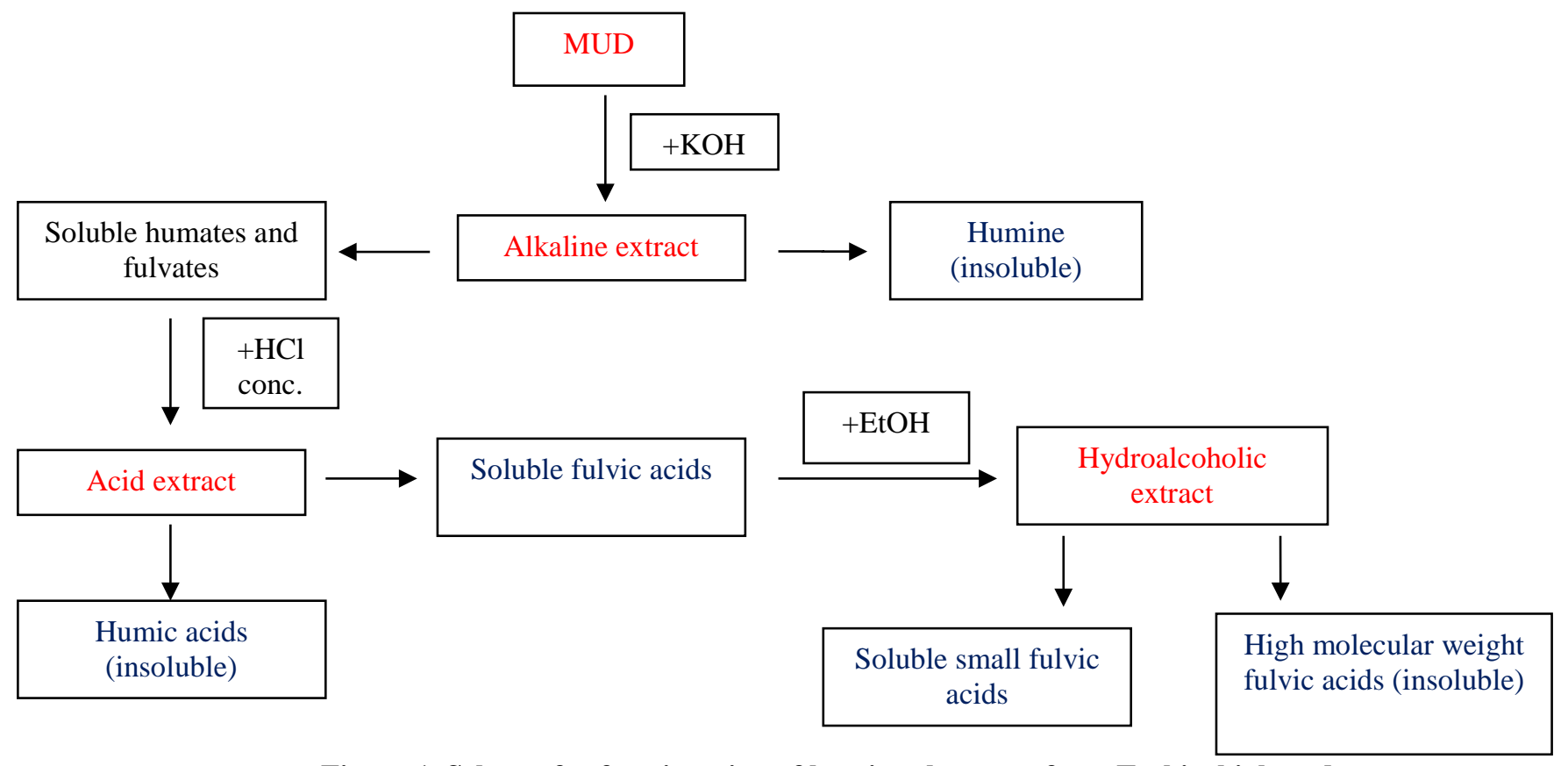

Figure 1. Scheme for fractionation of humic substances from Techirghiol mud

As a result of fractionation has been found that the Techirghiol mud containing $5.065 \mathrm{mg} / \mathrm{g}$ humic acid, $0.110 \mathrm{mg} / \mathrm{g}$ of low molecular weight fulvic acids and $0.024 \mathrm{mg} / \mathrm{g}$ high molecular weight fulvic acids (Table 2).

Table 2. Composition of humic substances in Techirghiol mud

\begin{tabular}{|l|r|}
\hline Humic substance & $\begin{array}{l}\text { Concentration } \\
\text { (mg/g mud) }\end{array}$ \\
\hline Humic acids & 5.065 \\
\hline Total fulvic acids & 0.135 \\
\hline Low molecular weight fulvic acids & 0.110 \\
\hline High molecular weight fulvic acids & 0.024 \\
\hline
\end{tabular}

The absorption spectra in the range of 340-700 nm (Figures 2-4) show the general characteristics observed for humic substances, decreasing with the increase of the wavelength in an exponential form described by a function of type $a(\lambda)=a(\lambda r) e-\operatorname{Se}(\lambda-\lambda r)$.

The alkaline extract spectrum reflects the properties of the $\mathrm{pH} 1$ low insoluble humic acid fraction with a high content of acid and aromatic groups but a low content of $\mathrm{O}$ and $\mathrm{N}$ groups and the remaining fraction in the solution are mainly composed of extremely rich organic material aromatic and aliphatic (Baglieri et al., 2014).
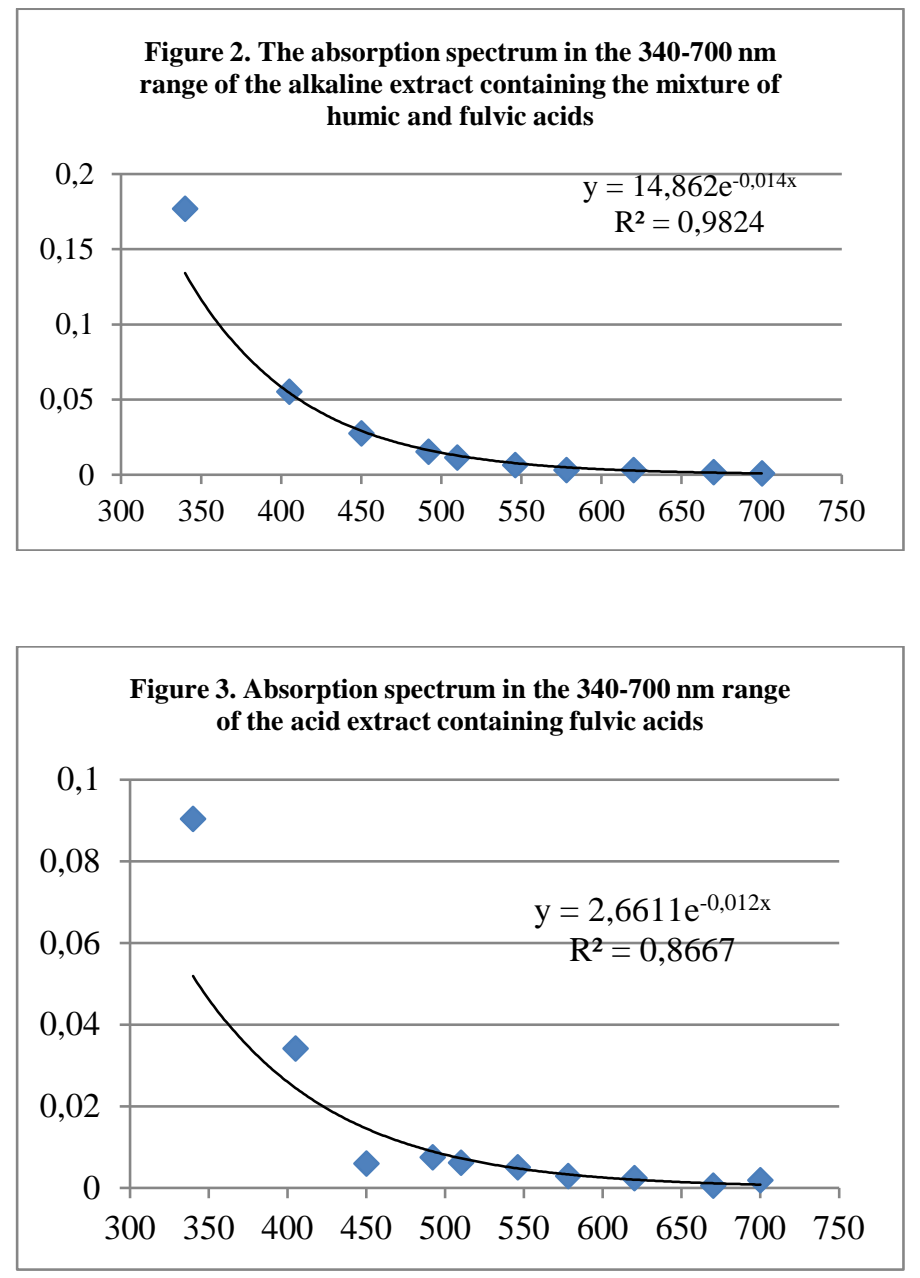


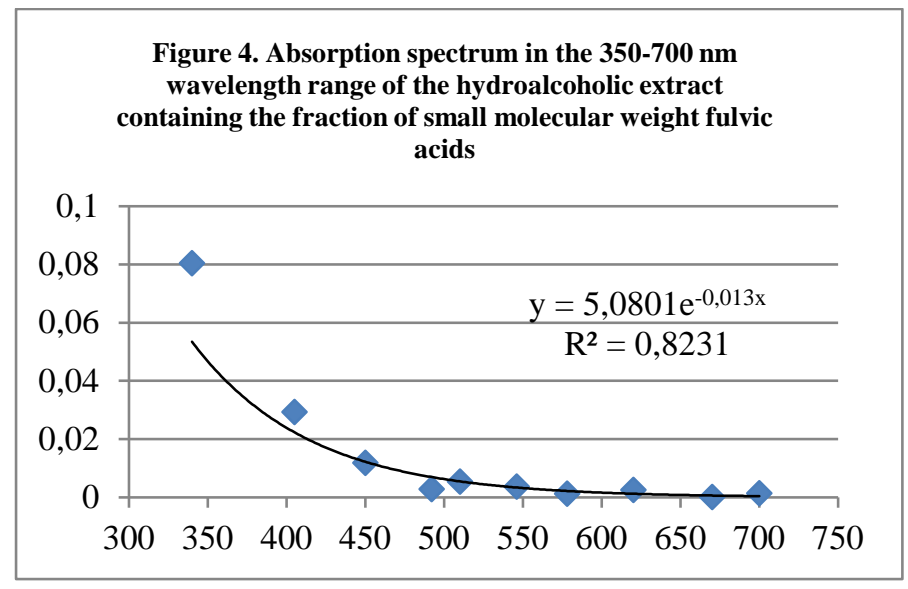

The quality of organic substances in peloids is evaluated by two methods, namely the ratio of humic acids to fulvic acids and the ratio of the absorbances of the alkaline extract to 465 and $665 \mathrm{~nm}$. (Stevenson, 1994). The lower these values, the more humic substances are more polymerized and more stable. It is considered that the absorbance value at the wavelength of 400-464 nm defines the content of the substances at the initial humification stage and at $\lambda$ 600-664 $\mathrm{nm}$ at the final humification stage. As shown in Table 2 and 3, the ratio of humic and fulvic acids to Techirghiol's sapropelic mud is 37.52 and $\mathrm{A}_{450} / \mathrm{A}_{670}$ decreases from 14.53 to 8.50 in the hydroalcoholic extract. These values are comparable to those of fulvic acids for which the $\mathrm{A}_{450} / \mathrm{A}_{670}$ ratio is between 6 and 18.5 (Kononova, 1966).

Table 3. Value of characteristic parameters for Techirghiol sapropelic mud extracts in the wavelength range $340-700 \mathrm{~nm}$

\begin{tabular}{|l|r|r|l|}
\hline & $\begin{array}{l}\text { Alkaline } \\
\text { extract }\end{array}$ & $\begin{array}{l}\text { Acid } \\
\text { extract }\end{array}$ & $\begin{array}{l}\text { Hydroalcoholic } \\
\text { extract }\end{array}$ \\
\hline $\mathrm{A}_{450} / \mathrm{A}_{670}$ & 14.53 & 10 & 8.5 \\
\hline$\Delta \log \mathrm{K}$ & 1.25 & 1.15 & 1.07 \\
\hline
\end{tabular}

The $\Delta \log \mathrm{K}$ parameter decreases from 1.25 in the alkaline extract to 1.07 in the hydroalcoholic extract, indicating an increase in humification (Niemiałkowska - Butrym, 2012) as fulvic acids are purified and the humic acids precipitated in the acid extract.

\section{Conclusions}

The values of some parameters of Techirghiol sapropelic mud composition and their distribution between the solid and the liquid phase were determined and the variance of the absorption in the solid phase for the inorganic compounds was $\mathrm{P}>\mathrm{Mg}$ $>\mathrm{Fe}>\mathrm{Ca}$ and for the organic compounds Carbohydrates $>$ Protein substances (including with catalytic activity) $>$ Lipids.

A new specific fractionation scheme is proposed to separate and characterize spectrophotometrically the compounds of humic substances specific to peloids and Techirghiol sapropelic mud.

\section{References}

1. Baglieri, A., Vindrola, D., Gennari, M., Negre, M., Chemical and spectroscopic characterization of insoluble and soluble humic acid fractions at different $\mathrm{pH}$ values, Chemical and Biological Technologies in Agriculture 2014, 1:9.

2. Brigante $\mathrm{M}$, Zanini G, Avena $\mathrm{M}$, On the dissolution kinetics of humic acid particles: effects of $\mathrm{pH}$, temperature and $\mathrm{Ca} 2+$ concentration, Colloids Surf A: Physicochem Eng Aspects (2007) 294:64-70.

3. Bucolo $G$ and David H. Quantitative determination of serum triglycerides by use of enzymes. Clin Chem 1973; 19: 476482.

4. Carretero, M. I., Gomes, C., Tateo, F.Clays and human health. In: F. Bergaya, B.K.G., Theng, G. Lagaly (Eds.), Handbook of Clay Science, Elsevier,Amsterdam, 2006, 717741.

5. Chromýa V., Svoboda V., and Štepánová I. Spectrophotometric determination of magnesium in biological fluids with xylidyl blue II. Biochem Med 1973, 7/2: 208-217.

6. Enkh-Oyun T., Tsatsralt Ts., Bayarmaa J., Isolation of bioactive substance from pure mumie. Journal of agricultural sciences №11 (02):33-35, 2013

7. Fourti, O., Jedidi, N., Hassen, A.: Humic substances change during the cocomposting process of municipal solid wastes and sewage mud. World J. Microbiol. Biotechnol., 26, 2010, 2117-2122.

8. Gamst $\mathrm{O}$ and Try K. Determination of serum-phosphate without deproteinization by ultraviolet spectrophotometry of the phosphomolybdic acid complex. Scand J Clin Lab Invest 1980; 40: 483-486.

9. Gan D., Evaluation of a spectrophotometric method for practical and cost effective quantification of fulvic acid. Annals of Environmental Science / 2007, Vol 1, 11-15

10. Gomes, C., Carretero, M.I., Pozo, M., Maraver, F., Cantista, P., Armijo, F., Legido, J.L., Teixeira, F., Rautureau, M., Delgado, R.Peloids and pelotherapy: Historical evolution, 
classification and glossary, Applied Clay Science, 75-76, 2013, 28-38.

11. Gornall AG, Bardawill CS, David MM. Determination of serum proteins by means of the Biuret reaction. J Biol Chem 1949; 177: 751-766.

12. Helal, A. A., Murad, G.A., Helal, A.A. Characterization of different humic materials by various analytical techniques. Arabian Journal of Chemistry (2011) 4, 51-54.

13. IFCC primary reference procedures for the measurement of catalytic activity concentrations of enzymes at $37^{\circ} \mathrm{C}$. Part 9 . Reference procedure for the measurement of catalytic concentration of alkaline phosphatase. Clin Chem Lab Med 2011; 49:1439-1446.

14. Keiluweit M., Kleber, M. Molecular Level Interactions in Soils and Sediments: The Role of Aromatic $\pi$ Systems, Environ. Sci. Technol. 43 (10), 3421- 3429 (2009).

15. Kononova M.M., 1966. Soil organic matter. Pergamon, Elmsford, N.Y.

16. Kosobucki P., Buszewski B., Natural organic matter in ecosystems -a review, Nova Biotechnologica et Chimica 132 (2014).

17. Lamar A New Standardized Method for Quantification of Humic and Fulvic Acids in Humic Ores and Commercial Products. JournaL of AOAC InternatIonaL Vol. 97, no. 3, 2014

18. Ma'or Z, Henis Y, Alon Y, Orlov E, Sørensen KB, Oren A. Antimicrobial properties of Dead Sea black mineral mud. Int J Dermatol. 2006; 45(5):504-11

19. Michaylova V, Illkova P. Photometric determination of micro amounts of calcium with Arsenazo III. Anal Chim Acta 1971; 53:194-198.

20. Milanovskii E. Yu.,Shein E. V., Functional Role of Amphiphilic Humus Components in Humus Structure Formation and Soil Genesis, Eur. Soil Sci. 35 (10), 10641075 (2002).

21. Munteanu Constantin - Cell biology considerations in Spinal Cord Injury - Review, Balneo Research Journal, 2017; 8(3): 152-200 Full Text DOI 10.12680/balneo.2017.150

22. Munteanu C., Munteanu D., Hoteteu M. - Balneotherapy and Healthy Ageing - review, Balneo Research Journal, 2014; 5(2): 68-81 Full Text DOI 10.12680/balneo.2014.1066

23. Munteanu C., Hoteteu M. - Estrogenic compounds endocrine disruptors, Balneo Research Journal, 2011; 2(4): 115-118 Full Text DOI 10.12680/balneo.2014.1021

24. Niemiałkowska-Butrym I., Talarowska A., Sokołowska Z., BogutaP., Optical Properties Of Humic Acids In Selected Organic Wastes, Acta Agrophysica, 2012, 19(4), 773-785

25. Potpara, Z., Duborija-Kovačević, N. Effects of the peloid cream from the montenegrin adriatic coast on skin humidity, transepidermal water loss and erythema index, examined with skin bioengeneering in vivo methods, Farmacia, 2012, Vol. 60, 4, 524-34.

26. Saito B.and Seckler M. M.. Alkaline extraction of humic substances from peat applied to organic-mineral fertilizer production. Brazilian Journal of Chemical Engineering Vol. 31, No. 03, pp. 675 - 682, July - September, 2014

27. Savel'eva, A.V., Yudina, N.V., Inisheva, L.I.: Composition of humic acids in peats with various degrees of humification. Solid Fuel Chem., 44, 2010, 305-309.
28. Stevenson F. J., Humus Chemistry: Genesis, Composi tion, Reactions (John Wiley \& Sons, New York, 1994).

29. Stookey LL. Ferrozine-A new spectrophotometric reagent for iron. Anal Chem 1970; 42: 779-81.

30. Trinder P. Determination of glucose in blood using glucose oxidase with an alternative oxygen acceptor. Ann Clin Biochem 1969; 6: 24-27.

31. Tsarfis P.G., Kiselev V.B., 1990. Healing mud and natural thermoconductor. Visshaya shcola, Moscow, Russia.

32. Tserenkhand, B., Badnainyambuu, Z.,Composition and classification of some peloids in the western region of Mongolia, Journal of Chemical Technology and Metallurgy, 51, 5, 2016, 570-576.

33. Veniale, F., Bettero ,A., Jobstraibizer, P.G., Setti, M.Thermal muds: perspectives of innovations, Applied Clay Science, 36, 2007, 141-147.

34. Yamauchi, M., Katayama, S., Todoroki, T., Watanable, T.,Total synthesis of fulvic acid. Journal of the Chemical Society, Chemical CommunicationS (23): 1565-6. (1984). 